\title{
Uber: A New Challenge for Regulation and Competition Law?*
}

\author{
Margherita Colangelo ${ }^{\star *}$ \\ Mariateresa Maggiolino ${ }^{* *}$
}

\begin{abstract}
The rise of new software platforms presents regulators and antitrust agencies all over the world with a challenge. Should regulations adapt to the new services of the digital economy? Should competition law change its paradigm in relation to the sharing economy? Despite the growing expansion of these services, in most countries there is still no regulatory framework addressing these problems. Uber is the most emblematic example of this phenomenon. Indeed, it is subject to a large number of ongoing lawsuits merging many issues, ranging from questions pertaining to labour law to problems connected with unfair competition laws. This article first analyses the particular business model adopted by Uber and the antitrust concerns that it could raise. In so doing, the article pays heed to the approach that antitrust authorities should take towards the complex rivalry between (regulated) incumbents and (unregulated) new entrants. The article then considers the legal nature of the services provided by Uber, i.e. whether they should be considered as transport services or as services of the information society. Either way, the chosen characterisation will affect the law applied to all digital platforms. The analysis, which adopts a comparative approach, focuses on the European context where national courts are in great turmoil and the CJEU will be issuing a preliminary ruling on the nature of Uber services.
\end{abstract}

KEYWORDS: sharing economy; taxi services; Uber; regulation; competition

\footnotetext{
${ }^{*}$ Date of reception: 29 July 2017. Date of acceptance: 02 September 2017.

${ }^{* *}$ Associate Professor, University of Roma Tre, Department of Law, 00154 Rome, Italy. margherita. colangelo@uniroma3.it.

${ }^{* * *}$ Associate Professor, Bocconi University, Department of Legal Studies, 20100 Milan, Italy. mariateresa.maggiolino@unibocconi.it.

This Article is the result of a common endeavour. Paragraphs 2 and 5 are by Mariateresa Maggiolino; paragraphs 3 and 4 are by Margherita Colangelo.
} 


\section{Introduction}

Uber facilitates the daily lives of many individuals. However, no final word as to its legal characterisation has yet been forthcoming. It evokes the sharing economy phenomenon because it fully exploits resources that would otherwise be underutilised. It provides transportation services without being subject to those parts of national regulations that preside over taxi services. It can be deemed an "information society service" because of its digital platform.

Thus, the article first analyses the features of Uber in the light of its relationship with the so-called "sharing economy" (paragraph 2). Then, it examines the impact of Uber on taxi industry and the regulatory challenges it poses (paragraph 3). Afterwards, it develops an overview on the main legal disputes involving Uber at the national and European levels (paragraphs 3 and 4). Finally, the article focuses on the antitrust implications of Uber business model (paragraph 5). In so doing, the article is among the few offering an overall discussion of regulation-antitrust interface that catches Uber. In particular, it concludes that national regulations relating to transport services should be updated not to stifle digital platforms like Uber, but to enable traditional taxis to embrace new technologies. As the experience of liberalised industries suggests, the displacement effect that Uber's innovation brought about should not be wasted, because its contribution has enhanced competition in the industry sector. In addition, as the experience of copyright piracy shows, the conflict between Uber and taxis could be resolved if traditional service providers were also to embrace the same (or even better) digital solutions to better satisfy the wants and needs of consumers legally.

\section{The sharing economy and Uber}

Itis difficult to say who the first to use the "sharing economy" label was. What is clear, however, is that only ten years ago the advent of digital platforms was welcomed as an alternative to consumerism and the traditional model of private, individual ownership. ${ }^{1}$ On those platforms, individuals gained the opportunity to re-design the way in which they consume, own, and work. Instead of enabling companies to sell their goods and services, those platforms allowed peers to benefit from joint access to prod-

\footnotetext{
${ }^{1}$ Yochai Benkler, "Sharing Nicely: On Shareable Goods and the Emergence of Sharing as a Modality of Economic Production", Yale L.J. 114 (2004): 273.
} 
ucts and skills. There, individuals could share, barter, lend, rent, gift, and swap resources ${ }^{2}$ that would otherwise be underutilised. ${ }^{3}$ Then, as to the purposes of this "collaborative consumption" facilitating relationships that otherwise might be too costly or burdensome to arrange, ${ }^{4}$ it was almost commonplace for digital platforms to help people not only save time and resources, but also make friends ${ }^{5}$ and become more active citizens. ${ }^{6}$ Hence, overall, the sharing economy phenomenon was linked to positive social changes leading to a new form of sustainable economy.

However, there is room to argue that "sharing" is not an accurate description of the services that run on digital platforms like Uber. ${ }^{7}$ True, Uber matches workers and underemployed individuals with those in need of taxi services and, hence, enables individuals to communicate and collaborate more effectively and efficiently. ${ }^{8}$ In addition, it is true that, unlike an online storefront, Uber does not directly provide any goods or services. Yet, users pay money and drivers work for profit. Furthermore, Uber is not a passive web portal or mobile application hosting the many transactions occurring between consumers and drivers. Uber supplies the electronic payment system, guarantees that pricing works dynamically, organises the listings, charges a fee for each exchange, and issues minimum quality standards for

\footnotetext{
${ }^{2}$ Rachel Botsman and Roo Rogers, What's Mine Is Yours: The Rise of Collaborative Consumption (New York: Harper Collins, 2010).

${ }^{3}$ Molly Cohen and Corey Zehngebot, "What's Old Becomes New: Regulating the Sharing Economy", Boston B.J. 58 (2014): 6; Bryant Cannon and Hanna Chung, "A Framework for Designing Co-Regulation Models Well-Adapted to Technology-Facilitated Sharing Economies", Santa Clara High Tech. L.J. 31 (2015): 23.

${ }^{4}$ Roberta A. Kaplan, "Regulation and the Sharing Economy", N.Y. L.J. (2014).

${ }^{5}$ Indeed, many sharing platforms enable users to create their own profiles and chat. This embedded social networking feature works also to fuel a reputation system made of review and rating tools - a reputation system that, in turn, serves to counterbalance the risks that users run by contracting with strangers in lieu of larger well-established businesses.

${ }^{6}$ Bronwen Morgan and Declan Kuch, "Radical Transactionalism: Legal Consciousness, Diverse Economies, and the Sharing Economy”, J.L. Soc'Y 42 (2015): 556, 557; Janelle Orsi, Practicing Law in The Sharing Economy: Helping People Build Cooperatives, Social Enterprise, and Local Sustainable Economies (Chicago: American Bar Association, 2012).

${ }^{7}$ Giana M. Eckhardt and Fleura Bardhi, "The Sharing Economy Isn't About Sharing at All”, Harv. Bus. Rev. (Jan. 28, 2015), accessed July 15, 2017. https://hbr.org/2015/01/the-sharing-economy-isnt-about-sharing-at-all.

${ }^{8}$ Talia G. Loucks, "Travelers Beware: Tort Liability in the Sharing Economy", Wash. J.L. Tech. \& Arts 10 (2015): 329, 330.
} 
drivers. In other words, Uber falls somewhere along a spectrum between purely hosting platforms and direct service providers. ${ }^{9}$

It may be that this incorrect association between Uber-like platforms and the sharing economy is a subterfuge for avoiding the regulation that traditionally governs the corresponding for-profit off-line services. It may be that the new technologies have actually deprived of meaning some of the rules set forth by the existing regulatory schemes and thus encouraged a change in the mindset of regulators. ${ }^{10}$ Either way, the relationship between Uber-like platforms and regulations must be put under scrutiny, as this article does, starting from how Uber fits into the many national regulations that preside over the taxi industry.

\section{Uber and the regulation governing the taxi industry}

Rules governing transport of passengers services via platforms are the subject of debate in many jurisdictions, particularly in those where Uber has started (or tried to start) operating through one or more types of the activities provided by its business model, as it includes several options that vary depending on the features of the drivers and vehicles. The two main (and controversial) services provided by Uber are UberPop (whereby, against the payment of a fee, users connect to drivers that do not hold any professional taxi/chauffeur licences) and UberBlack (where the app links consumers to private licenced professional drivers operating services with rental cars). It is well known that, despite the differences between the countries concerned, there has been a general and strong reaction by taxi drivers against Uber (and similar platforms, such as Lyft).

The taxi industry is one of the most heavily regulated in the majority of countries all over the world, with varying degrees of difference in the forms of quantity regulation, quality regulation, market conduct regulation and price regulation. ${ }^{11}$ With regard to the first type of regulation, the most controversial concern is that it typically involves control of entry, with the regulator/local authorities setting the maximum number of operators that may provide taxi services, and frequently exercising discretion over the issue of new licences. Quality regulation sets licensing and performance

\footnotetext{
9 Vanessa Katz, "Regulating the Sharing Economy", Berkeley Tech. L.J. 30 (2015): 1067, 1071-1072.

${ }^{10}$ Nathan Cortez, "Regulating Disruptive Innovation", Berkeley Tech. L.J. 29 (2014): 175 and Christopher Koopman, et al., "The Sharing Economy and Consumer Protection Regulation: The Case for Policy Change", J. Bus. Entrepreneurship \& L. 8 (2015): 529, 544.

${ }^{11}$ OECD, Taxi Services: Competition and Regulation, 2007, 19.
} 
requirements for the drivers and the taxi companies aimed at ensuring safety standards for both drivers and vehicles, in addition to setting financial responsibility standards (such as compulsory insurance). Moreover, market conduct regulation can include requirements for taxis to pick up all passengers (the so-called "cab rank principle"). ${ }^{12}$ Finally, price regulation provides for the setting of maximum rates based on various methodologies.

In general, taxi services enjoy greater protection than other transportation services because of their supplementary role in public passenger transportation at local level. Several justifications for such a pervasive role of public regulation are traditionally adduced. Among them, the main arguments include the idea that in the absence of control on entry there would be an excessive number of taxis, creating congestion and pollution on the one hand, and disastrous competition between them on the other, thereby affecting the quality of the service provided. Regulation is also supposed to grant the fairness and reasonableness of the fares applied to passengers, together with passenger safety.

In reality, in most countries what has been seen in practice demonstrates that regulation has failed to obtain efficient results in this sector more than any other. In fact, control over entry has led in many cases to an undersupply of the service, a typical complaint being the lack of sufficient cars available during peak hours or in certain areas. Furthermore, control over prices and quality has not incentivised taxi companies to innovate or implement quality of service. More generally, empirical evidence demonstrates that the taxi industry is subject to regulatory capture in several jurisdictions. ${ }^{13}$ Nevertheless, the beneficial outcomes achieved by the experience of deregulation in some countries are not unanimously shared by economic literature, even if the majority are in favour of it. ${ }^{14}$

Uber has burst into this industry as a disruptive element, showing how technological advances have created new ways to operate the service of carriage of persons and bringing traditional taxi services into question, thereby reopening the debate on their inefficiencies and the need for reform of the rules governing the sector. ${ }^{15}$ Already, the use of Internet-based mobile

${ }^{12}$ OECD, Taxi Services: Competition and Regulation, 20 ff. For a brief overview, see also Damien Geradin, "Should Uber be Allowed to Compete in Europe? And if so how?", CPI (2015): 4.

${ }^{13}$ OECD, Taxi Services, $31 \mathrm{ff}$.

${ }^{14}$ See the survey provided by Adrian T. Moore and Ted Balaker, "Do Economists Reach a Conclusion on Taxi Deregulation?", Economic Journal Watch 3 (2006): 109.

${ }^{15}$ On the "disruption model" followed by Uber, see Nicolas P. Terry, "Regulatory Disruption and Arbitrage in Healthcare Data Proceedings", Yale J. Health Pol'y, Law, \& Ethics 17 (2017): 143, 156- 
technology to match passengers and drivers has created unprecedented competition in the taxi industry. ${ }^{16}$ As a result, incumbent operators, which have benefitted from a substantial and lasting lack of competition in the market, have tried to stop the advent of Uber. Not only have they been lobbying governments to impose bans and restrictions on Uber's activities, but they have also brought several lawsuits claiming that Uber competes unfairly with traditional taxi operators as it does not meet the regulatory requirements with which they have to comply. In the European Union, there is lively debate around this issue. Yet, so far, regulators and courts have provided no uniform or final answer as to whether the services that Uber offers should fall under transport regulation because they are equivalent to taxi services. ${ }^{17}$

France was the first country outside the US where Uber started operating. There, Uber's activity caused considerable legal disputes of varying nature (civil, criminal, administrative and constitutional). Initially, the entry of new operators into the market was facilitated by the provisions of the Loi Novelli, liberalising the market of hire cars with driver (voiture de transport avec chauffeur, hereinafter VTC).$^{18}$ VTCs differ from taxis, as they are not subject to any requirement and can only accept pre-arranged dispatch assignments; it is only taxis which hold an exclusive right to accept street hail and to pick up passengers at designated taxi ranks. In addition, they can service dispatch requests for pre-arranged pickups. Thus, it is no surprise that VTCs, together with Uber and other digital start-ups, provoked the protests of taxi drivers. These remonstrations led the French government to amend the applicable rules up to the significant revision introduced by the

\footnotetext{
158; Mark Anderson and Max Huffman, "The Sharing Economy Meets the Sherman Act: Is Uber a Firm, a Cartel, or Something in Between?", Columbia Business Law Review (forthcoming); Indiana University Robert H. McKinney School of Law Research Paper No. 2017-8, accessed July 15, 2017. https://ssrn.com/abstract=2954632. For a wide analysis of the effects of Uber on safety, privacy, discrimination, and labour standards, see Brishen Rogers, "The Social Costs of Uber", University of Chicago Law Review Online 82 (2015): 85, accessed July 15, 2017. http://chicagounbound.uchicago. edu/uclrev_online/vol82/iss1/6.

${ }^{16}$ Judd Cramer and Alan B. Krueger, "Disruptive Change in the Taxi Business: The Case of Uber", American Economic Review 106 (2016): 177.

${ }^{17}$ For an overview on legal disputes concerning Uber in Europe, see reports published in Journal of European Consumer and Market Law 1-2 (2015): 59-67.

${ }^{18}$ Loi n ${ }^{\circ} 2009-888$ du 22 juillet 2009 de développement et de modernisation des services touristiques, JORF No 0169, 24 July 2009, 12352.
} 
Loi Thévenoud. ${ }^{19}$ Whilst establishing some common principles for the allsector operators, it contained some specific rules which assist taxis. Among them, the confirmation of the legal monopoly on the maraude, i.e. the right to circulate, stop on the street, and accept street hail; the ban on the electronic maraude (i.e. the geo-localisation through smartphone application); and a series of specific provisions anti-maraude to be applied to VTCs. ${ }^{20}$ Meanwhile, Uber was unsuccessful in many lawsuits, starting in 2014 with the first decision issued by the Tribunal de commerce de Paris. ${ }^{21}$ Other judgements followed, focussing mainly on the UberPop service, culminating in the governmental ban on it and in the submission of priority issues of constitutionality of the Loi Thévenoud. ${ }^{22}$ Then, the Conseil constitution$n e l$, among the various issues submitted, upheld the ban on UberPop. ${ }^{23}$

Several lawsuits were also filed in Germany, where in 2014 the local authority in Berlin banned the use of Uber's platform on the grounds of risk to consumers due to the lack of monitoring on vehicles and drivers. The same then happened in other German cities. The debate concerned the issues of the compatibility of UberPop and UberBlack with the national rules on transportation of passengers (Personenbeförderungsgesetz, PBefG) and on unfair competition (Gesetz gegen den unlauteren Wettbewerb, UWG). The issue of the legal qualification of Uber has not been developed by courts dealing with national competition law questions, which have generally concluded that Uber services constitute unfair competition. Administrative courts in Berlin and Hamburg have, instead, concluded that, with regard to UberPop, it does not comply with the requirements

\footnotetext{
${ }^{19}$ Loi n ${ }^{\circ} 2014-1104$ du ler octobre 2014 relative aux taxis et aux voitures de transport avec chauffeur, JORF No 0228, 2 Oct 2014, 15938.

${ }^{20}$ Other provisions include the requirement for each covered driver to return to his base between rides if he does not have a reservation booked when dropping off a passenger, and the ban on the application of the hourly-kilometric rate. This latter provision has been cut off by the Constitutional Court.

${ }^{21}$ Tribunal de commerce de Paris, 1 Aug 2014, Association Française des Taxis; appeal: Cour d'appel de Paris, 19 Nov 2015, No 14/17915.

${ }^{22}$ Tribunal de grande instance de Paris, 16 Oct 2014; appeal: Cour d'appel de Paris, 7 Dec 2015; and, Tribunal de commerce de Paris, 12 Dec 2014; appeal: Cour d'appel de Paris, 5 April 2016.

${ }^{23}$ Conseil constitutionnel, decision No. 2015-468/469/472, 22 May 2015, Société UBER France SAS et autre; Ibid., decision No. 2015-484, 22 Sep 2015, Société UBER France SAS et autre; Ibid., decision No. 2016-516, 15 Jan 2016, M. Robert M. et autres. Then on December 2016 a new legislation was adopted (loi Grandguillaume, Loi n 2016-1920 du 29 décembre 2016 relative à la régulation, à la responsabilisation et à la simplification dans le secteur du transport public particulier de personnes, JORF No 0303, 30 Dec 2016).
} 
provided by national laws for licensing, safety and insurance cover, and rejected the qualification of Uber as a mere intermediary, playing the role of a sort of car-sharing agency, supporting a wide interpretation of Uber as a carrier. ${ }^{24}$ With regard to UberBlack, the same courts considered that Uber violates laws reserving taxis the right to wait at the roadside and pick up passengers and thus basically to blur the taxi and rental car services.

In Italy, UberPop was banned in 2014 after the judgements released by the Tribunale di Milano, ${ }^{25}$ while UberBlack was banned, and then readmitted by the Tribunale di Roma in May 2017. ${ }^{26}$ It is worth mentioning that the Constitutional Court, in December 2016, issued an important judgement declaring that a regional law limiting the carriage of passengers to taxis and NCC services (noleggio con conducente, i.e. hire cars with a driver) is illegitimate, as it comes under rules on the safeguard of competition, over which the State has exclusive competence. ${ }^{27}$ On that occasion the Court clarified that against the existing national legislation, dating back to the 90's, technological progress poses questions debated not only before courts ,but also in the political and regulatory contexts at both national and EU level: this would suggest the need for an updated and univocal regulatory framework to be met by the legislator.

National competition authorities (NCAs) have also intervened in the debate. Among them, the Italian Competition Authority (ICA) has taken a very clear stance. In March 2017, it formally invited the legislator to intervene in order to modernise and make the actual legislation more flexible, by creating a level playing field aimed at avoiding practices that can seem unfair and opening the sector to competition with beneficial effects for final consumers. ${ }^{28}$ The ICA has indicated three main points as crucial. Firstly, it suggested equalising taxi services and other kinds of similar transport. Secondly, it acknowledged that the advent of digital operators has completely modified market development and made obsolete the legislation in force. Thirdly, the ICA recommended the enactment of some legislative

\footnotetext{
${ }^{24}$ VG Hamburg, 27 Aug 2014, 5 E 3534/14 and OVG Hamburg, 24 Sep 2014; VG Berlin, 26 Sep 2014, VG 11 L 353.14 and OVG Berlin-Brandenburg, 10 Apr 2015, OVG 1 S 96.14.

${ }^{25}$ Tribunale di Milano, 25 May 2015, No. 16612/2015; 2 July 2015, Nos 35445/2015 and 36491/2015. See the comment of Valerio C. Romano, "Nuove Tecnologie per il Mitridatismo Regolamentare: Il Caso Uber Pop", Mercato concorrenza regole 1 (2015): 133. In 2017 the ban on UberPop was confirmed by the Tribunale di Torino, sez. I civile, 24 Mar 2017, No. 1553.

${ }^{26}$ Tribunale di Roma, sez. IX civile, 7 April 2017; Id., 26 May 2017, No. 25857.

${ }^{27}$ Corte costituzionale, 15 Dec 2016, No. 265.

${ }^{28}$ Autorità Garante della Concorrenza e del Mercato, 10 March 2017, S2782.
} 
tools to compensate the effects that the opening of the market has produced on the incumbent operators, forced to satisfy public service obligations.

\section{Transport services or services of the information society?}

When dealing with Uber services, it is clear that in order to establish which rules should be applied the main crucial issue is whether they should be labelled as "transport services" or "information society services". Given the complexity of the issue and the substantial lack of clarity over the proper legal qualification of Uber, some national courts have decided to refer to the European Court of Justice (CJEU) for a preliminary ruling. This is the case of the Tribunal de Grande Instance de Lille, which in March 2016 condemned Uber for unfair commercial practices. Again, Germany's Federal Court of Justice (Bundesgerichtshof) dealing with UberBlack referred the case to the CJEU in May 2017. Before them, in August 2015 the Juzgado de lo Mercantil No 3 (Commercial Court) of Barcelona sent the first request to the CJEU regarding the rules to be applied to Uber Spain, operating in Barcelona, Madrid and Valencia without the licences and the authorisations required by the national laws for taxis. ${ }^{29}$

As usual, the Spanish case arises from an action brought by a trade association (Elite Taxi), asking the court to declare that Uber Spain's activity in the form of UberPop constitutes an act of unfair competition and to order it to cease its conduct. The core issue of the questions referred by the national court is whether Uber's activity falls within the scope of Directives $2006 / 123$ and 2000/31 as well as the provisions of the TFEU on the freedom to provide services. The judgement of the Court is still awaited, but Advocate General (AG) Szpunar has recently released his opinion, giving a crucial interpretation of the controversial questions at issue. ${ }^{30}$

Within the meaning of Article 1(2) of Directive 98/34, an information society service is a service provided for remuneration, at a distance, by electronic means and at the individual request of a recipient. Given the relevant EU regulatory framework, the reasoning of the AG develops on the following points, starting from the analysis of the main features of Uber's

${ }^{29}$ Case C-434/15, Request for a preliminary ruling from the Juzgado Mercantil No 3 de Barcelona (Spain) lodged on 7 August 2015 - Asociación Profesional Élite Taxi v Uber Systems Spain, OJ 2015, C 363/21. For a comment, see Damien Geradin, "Online Intermediation Platforms and Free Trade Principles - Some Reflections on the Uber Preliminary Ruling Case”, April 2016, accessed July 15, 2017. https://ssrn.com/abstract=2759379.

${ }^{30}$ Opinion of Advocate General Szpunar of 11 May 2017, Asociación Profesional Élite Taxi v Uber Systems Spain, C-434/15, EU:C:2017:364. 
activity, i.e. that drivers on the Uber platform offer passengers a transport service to a destination selected by the passenger and receive the payment whose amount far exceeds the mere reimbursement of expenses incurred. This would in turn exclude that Uber is a ride-sharing platform as well as a mere intermediary who simply matches supply to demand. Above all, the activity of Uber being a composite service, i.e. comprising electronic and non-electronic elements, where the former is not the main one and is not economically independent of the latter, it cannot be classified as an information society service within the meaning of Directive 2000/31. More specifically, the AG notes that Uber allows persons wishing to pursue the activity of urban passenger transport to connect to its application and carry out that activity subject to the terms and conditions imposed by Uber itself, which are binding on drivers by means of the contract for use of the application. The numerous terms and conditions included in the contract cover both the taking up and pursuit of the activity and the conduct of drivers when providing services. In addition, Uber sets the final price of the service provided. ${ }^{31}$ It follows, according to the AG, that Uber is a "genuine organiser and operator of urban transport services", i.e. a traditional transport service. ${ }^{32}$ In a more recent preliminary ruling case, pending before the Court of Justice and concerning Uber France, the AG has confirmed this view. ${ }^{33}$

Such a qualification clashes with the view expressed by some scholars before the release of the conclusions of the AG. For instance, Geradin has affirmed that UberPop would fit with the definition of information society service under Directive 98/34, as it meets all the elements required, i.e. the provision of the service "at a distance" (since the service is provided without the driver and the rider being simultaneously present), "electronic means" (since it is provided by a mobile software application), "at the individual

\footnotetext{
${ }^{31}$ See paragraph 50: "Although Uber's representatives stated at the hearing that drivers are, in principle, free to ask for a lower fare than that indicated by the application, this does not seem to me to be a genuinely feasible option for drivers. Although drivers are theoretically given such a discretion, the fee Uber charges is the amount resulting from the fare as calculated by the application. Since any reduction in the fare paid by the passenger is to the detriment of the driver, it is unlikely that drivers would exercise that discretion".

${ }^{32}$ Paragraph 61.

${ }^{33}$ Opinion of Advocate General Szpunar of 4 July 2017, Uber France SAS., C-320/16, EU:C:2017:511. This case concerns the question whether certain provisions of French law which apply to services such as those offered by Uber should have been notified as rules on services within the meaning of the provisions of EU law on technical notification.
} 
request of a recipient of services" (since it is provided upon request of the users through the connection to Uber platform) and "normally provided for remuneration" (since the driver expects a payment for transporting the rider).$^{34}$ According to this approach, Uber has nothing to do with traditional transport services, such as those provided by taxi companies, but belongs to the category of "online market-making platform", ${ }^{35}$ creating value by enabling interactions between distinct categories of users, and not by performing transport activities. In other words, Uber is a typical two/multi-sided platform, one of the main examples of what Evans and Schmalensee call "matchmakers", connecting drivers and riders, which are linked by indirect network effects, as a large number of drivers benefit riders, and vice-versa. ${ }^{36}$

A very different view is supported by AG Szpunar, which directly addresses the question of the comparison with other intermediation platforms, namely with those used to make hotel bookings or purchase flights. ${ }^{37}$ Although he acknowledges that some similarities exist (e.g. as regards the mechanisms for booking or purchasing directly on the platform, the payment facilities, the ratings systems), he argues that in those cases hotels and airlines are undertakings which function completely independently of any intermediary platform. The AG points out that the crucial difference lies in the fact that hotels and airlines and not the booking platforms determine prices and conditions under which their services are provided. In reality, this assumption seems to collide with the stance taken by the Commission

${ }^{34}$ Geradin, "Online Intermediation Platforms", 8-9.

${ }^{35}$ Ibid.

${ }^{36}$ David S. Evans and Richard Schmalensee, Matchmakers. Harvard: Harvard Business Review Press, 2016. The terminology of two-sided and multi-sided markets derives from economic literature. The expression "two-sided markets" appears in the seminal work of Jean-Charles Rochet and Jean Tirole, "Platform Competition in Two-Sided Markets", J. Eur. Econ. Ass'n 1 (2003): 990. Among the huge economic literature on this issue, see also: David S. Evans, "The Antitrust Economics of Multi-Sided Platform Markets", JREG 20 (2003): 325; Bernard Caillaud and Bruno Jullien, "Competing Cybermediaries", Eur. Econ. Rev. 45 (2001): 797; Bernard Caillaud and Bruno Jullien, "Chicken and Egg: Competition among Intermediation Service Providers", RAND J. Econ. 34 (2003): 309; Geoffrey Parker and Marshall W. Van Alstyne, "Two-Sided Network Effects: A Theory of Information Product Design", Mgmt. Sci. 51 (2005): 1494; Mark Armstrong, "Competition in Two-Sided Markets", RAND J. Econ. 37 (2006): 688. In general, the fundamental features of two-sided markets are: distinct groups of customers who rely on each other but also on the platform for intermediate transactions between them; indirect externalities across groups of users; and the non-neutrality of the price structure, meaning that the price structure of the platform affects the level of transactions.

${ }^{37}$ See paragraphs $59 \mathrm{ff}$. 
and several NCAs in the recent case law on online travel agencies (OTAs, e.g. Booking, Expedia, etc.). ${ }^{38}$ It has been found that such intermediaries are imposing essential conditions of the principals' pricing strategy by the widespread use of price parity clauses, which have been interpreted as a form of minimum resale price maintenance (RPM): this has precluded the establishment of a genuine agency relationship between them and the hotels concerned. ${ }^{39}$ This case law is not totally ignored by the AG, who mentions it in the footnotes arguing that the treatment of price parity clauses is immaterial in the analysis of Uber..$^{40}$ However, as the control over conditions and prices is assumed by him to have a crucial relevance in the assessment of the alleged independence of Uber as intermediary, it does not seem correct to fail to take into account the considerations mentioned above.

Rather than the pricing issue, a more accurate remark made by the AG regards the fact that, whereas Uber controls applicants' compliance with its own requirements, booking platforms do not exert any prior control on the hotels that have access to the platforms: hotels simply operate in accordance with the State/local rules specific to their sector. ${ }^{41}$ From this point of view, it is worth noting that Uber poses questions similar to those arising in respect of platforms such as Airbnb, as both are at odds with existing regulatory frameworks, which require licensing and other conditions (e.g.

\footnotetext{
${ }^{38}$ In the EU the main investigations on OTAs have been conducted by NCAs in the UK, Germany, Italy, France and Sweden. In particular, the Italian, French and Swedish NCAs have collaborated under the coordination of the EU Commission.

${ }^{39}$ On this topic, see, inter alia, Ariel Ezrachi, "The Competitive Effects of Parity Clauses on Online Commerce", European Competition Journal 11 (2015): 488; Pinar Akman, "A Competition Law Assessment of Platform Most-Favored-Customer Clauses", Journal of Competition Law and Economics 12 (2016): 781; Margherita Colangelo, "Parity Clauses and Competition Law in Digital Marketplaces: The Case of Online Hotel Booking", Journal of European Competition Law \& Practice 8 (2017): 3.

${ }^{40}$ See footnote 22 of the Opinion ("The fact that some platforms conclude rate parity agreements with hotels, under which hotels agree to refrain from offering rates elsewhere which are lower than those offered on the platform in question, is immaterial. These agreements do not involve the setting of prices for the services by the platform, but a commitment concerning the rate-related treatment of different trading partners").

${ }^{41}$ The AG considers another difference between booking platforms and Uber at paragraph 60: "Lastly, such booking platforms give users a real choice between several providers whose offers differ on a number of important points from the users' perspective, such as flight and accommodation standards, flight times and hotel location. By contrast, with Uber, these aspects are standardised and determined by the platform, so that, as a general rule, the passenger will accept the service of the most quickly available driver".
} 
insurance, etc.). ${ }^{42}$ This aspect looks at the main proceeding in the Spanish case at issue, one of the referred questions being whether the provisions of Directive 2000/31 prevent the imposition of penalties on Uber on account of unfair competition resulting from the activity of drivers providing transport services on that platform. The AG considers Uber responsible for its comprehensive system for on-demand transport and this would also be true in the case where an interpretation different from that supported by Szpunar were to be accepted, i.e. that the connection supply were to be regarded as independent of the supply of transport in the strict sense, since these two supplies would ultimately be performed by Uber or on its behalf. In any case Uber, at least as far as the UberPop service is concerned, cannot benefit from the liberalisation provided by Directive 2000/31, as it is organised in such a way that Uber cannot, as matters stand, comply with the requirements provided by the existing regulatory framework. ${ }^{43}$

Commenting on the opinion released by the AG, the main critical question appears to be whether it is correct to consider the provision of a transport service as the main purpose of Uber's activity, so that this would necessarily lead to the conclusion that Uber must be equated to a transport service provider subject to the traditional rules applied to transport. However, this opinion does not properly consider the features of platforms, among which Uber plays a unique and pioneer role, and the consequences that such approach may have, not only for Uber itself, but for online intermediation platforms in general. Should the Court of Justice confirm this view, this might constitute an influential source justifying the adoption of the restrictive approach that has prevailed in Member States up to now.

\section{Uber and Antitrust Law}

When addressing the Uber case, one could wonder whether and how antitrust law could target Uber practices. Actually, first and foremost, the antitrust toolkit helps to better analyse and understand Uber's business.

For example, according to the antitrust jargon, Uber adopts a two-sided business model that exploits the indirect network effects that exist between drivers and users. In other words, and as said before in commenting on the AG's opinion, Uber's platform flourishes not only because it enhances efficiency by reducing the underutilisation of cars and driving skills, but

\footnotetext{
${ }^{42}$ See Benjamin G. Edelman and Damien Geradin, "Efficiencies and Regulatory Shortcuts: How Should We Regulate Companies like Airbnb and Uber?”, Stan. Tech. L. Rev. 19 (2016): 293.

${ }^{43}$ Paragraphs 86-87.
} 
also because it enjoys a sort of self-reinforcing effect resulting from the twofold fact that a greater number of drivers attracts more users and viceversa. ${ }^{44}$ In knowing this, one should not overlook the fact that Uber is not a mere provider of some pieces of technology, such as the platform and the connected mobile application. Uber exists and grows because, by matching users and drivers via its platform, it exploits the interdependencies that occur between these two different demands: the demand of transportation and the demand of driving.

In addition, the antitrust analysis suggests that Uber platforms are a system of interoperable software combined in a complex architecture that is nevertheless flexible enough to embrace new components. This means that Uber can easily diversify its business, by associating other products and services with the platform, as it in fact did with Uber food. From an antitrust standpoint, this fact produces several consequences. On the one hand, it means that the competition occurring in digital markets is highly dynamic, not to say fluid, just because platforms can easily enter new markets by offering new and innovative functionalities. ${ }^{45}$ On the other hand, the same capacity of developing new services may permit Uber to profit from pre-emptive strategies that produce exclusionary, though not necessarily anticompetitive, effects. Indeed, those who enter new markets by offering novel functionalities to an already-established base of customers raise their rivals' costs, that is, they force their rivals to use less efficient and lower-quality technologies that make their offer less valuable than the offer of the new entrants. ${ }^{46}$ Once again, the antitrust analysis does not necessarily reveal the existence of unlawful conduct. Yet it serves a twofold aim: it improves our understanding of the business rationale underpinning Uber strategies and it highlights the necessity for the antitrust agencies and authorities to be rapid in their responses. ${ }^{47}$

\footnotetext{
${ }^{44}$ David S. Evans and Michael Noel, "Defining Antitrust Markets When Firms Operate Two-Sided Platforms", Colum. Bus. L. Rev. 3 (2005): 667.

${ }^{45}$ Already in Jeffrey Eisenach and Thomas M. Lenard (eds.), Competition, Innovation and the Microsoft Monopoly: Antitrust in the Digital Marketplace (Boston: Kluwer Academic Publisher, 1998).

${ }^{46}$ The literature about this kind of exclusionary strategies is huge. Thus, we refer to one of the leading contributions on the subject, Steven C. Salop and David T. Scheffman, "Raising Rivals' Costs", The American Economic Review 73 (1983): 267.

${ }^{47}$ See William E. Kovacic, "Antitrust in High-Tech Industries: Improving the Federal Antitrust Joint Venture", Geo. Mason L. Rev. 19 (2012): 1097, 1102 (observing that, "[t]he antitrust system pedals furiously on a bicycle to catch up with industry developments that speed ahead in a formula one car").
} 
Turning to Uber practices, antitrust law has nothing to say about Uber pricing. On the contrary, its "surge pricing" system, also named dynamic pricing system, mimics the textbook case of a market where prices - but in the case of Uber also the quantities, that is, the number of drivers available - adjust themselves almost instantly according to supply and demand. Unlike personalised prices, Uber's dynamic price does not change depending on the buyer's reserve price, but according to various factors such as: (a) the company's internal metrics (such as when a website that sells tickets for shows and sporting events changes its prices because of low traffic logs), (b) competitors' prices (when the company changes its prices to keep up with competitors), (c) the real-time matching of supply and demand (as often happens regarding the prices of airline tickets and hotel rooms), and (d) any other external elements (such as weather conditions, in the case of transport)..$^{48}$

A different issue, connected to prices, is whether the pricing system of Uber works as a "hub and spoke" tool, that is, as a central instrument - the "hub" - that coordinates the prices that drivers - the "spokes" - apply. ${ }^{49}$ This theoretical possibility has yet to be ascertained in practice, by exploring whether Uber's algorithm has actually been manipulated to reduce competition among drivers and fix their prices. Instead, if Uber's algorithm works as Uber declares it to work, that is, by mirroring how the market demand and supply change over time, no kind of collusion occurs and the case of two drivers charging the same price should be regarded as a coincidence due to market forces rather than as a parallel behaviour resulting from collusion.

In addition, antitrust law cannot (and should not) change the entry barriers that protect Uber's market power. Certainly, because of the abovementioned indirect network effects, any potential entrant should have on board enough users before challenging the incumbent. ${ }^{50}$ In addition, the user data that platforms collect while offering their services ${ }^{51}$ serve to hold

\footnotetext{
${ }^{48}$ See https://newsroom.uber.com/guest-post-a-deeper-look-at-ubers-dynamic-pricing-model, accessed July 15, 2017.

${ }^{49}$ Maurice E. Stucke and Ariel Ezrachi, Virtual Competition (Harvard: Harvard University Press, 2016), 50-55.

${ }^{50}$ See David S. Evans and Richard Schmalensee, "Failure to Launch: Critical Mass in Platform Businesses", (2010), accessed July 15, 2017. https://ssrn.com/abstract=1353502.

${ }^{51}$ When an individual uses Uber, the platform stores the data describing the individual's experience: the timing, the places, and the price. In this way, Uber can profile its users, as well as its drivers. Indeed, even Uber tracks drivers' routes and behaviours.
} 
back consumers. The more data the platform collects, the greater its ability to improve its services, the greater the amount of money that it can earn from one of its sides at least, and the higher the switching costs that consumers would bear if they changed platform..$^{52}$ However, firstly, network effects do not fall into the scope of antitrust law, because they are market features that do not depend on business practices. Secondly, the positive feedback loop that platforms enjoy due to user data collected is a by-product of an activity, that of using those data to improve services, that enhances consumer welfare and thus cannot be forbidden by antitrust law.

A different issue is whether, assuming taxi regulation should apply to Uber, antitrust law should act against Uber because it does not comply with those national/local regulations that govern taxi services. Actually, platforms like Uber have increased the output of the services available to consumers and reduced the market price of those services. Thus, the mere existence of Uber and its economic activity is not anticompetitive within the meaning of antitrust law, because it does not harm consumer welfare. And this conclusion holds true even if the evidence shows that Uber's business harms taxi drivers. Indeed, antitrust law does not aim to protect competitors: it wants markets to work as Darwinist mechanisms, including firms that smite their rivals because of their merits and excluding firms that are not as meritorious as their rivals.

Clearly, this does not mean that antitrust agencies and authorities support firms that act in spite of the law. In other words, there should be a single level playing field for Uber and taxi drivers. Yet, in this regard, antitrust enforcers have limited powers. They can only forbid anticompetitive agreements, mergers, and monopolistic practices. They cannot prescribe obligations and commitments to force, for example, Uber to comply with taxi regulations. Neither can they exempt taxi drivers from those regulatory obligations to which Uber is not subject. As shown by the Italian Competition Authority, who worked within the powers of its advocacy activity, when they are entitled and have the power to, antitrust enforcers intervene to guarantee a level playing field. ${ }^{53}$

A final issue that could be further developed in the future regards the review and rating systems that Uber provides. By and large, antitrust law

\footnotetext{
${ }^{52}$ Feedback loop is the label given to this phenomenon. For a clear explanation of it and a critique to its empirical soundness see Adres V. Lerner, "The Role of 'Big Data' in Online Platform Competition", (2014), accessed July 28, 2017. http://ssrn.com/abstract $=2482780$.

${ }^{53}$ Autorità Garante della Concorrenza e del Mercato, 10 March 2017, S2782.
} 
does not make inquiry into whether consumers are well-informed. It is true, there have been cases where antitrust authorities intervened against the false or misleading information that firms spread in the market. Yet, by tradition, consumer education and awareness have never been among the first tasks of competition authorities. ${ }^{54}$ By tradition, cases of false and misleading information fall within the scope of consumer protection law, disclosure regulation, and unfair competition.

However, since information is a product, antitrust law can be used to prosecute firms that, by exploiting their unilateral or aggregated market power, harm the well-functioning of the markets where many types of information are produced and distributed, ${ }^{55}$ with the ultimate goal of reducing the quantity and the quality of the information conveyed for consumers (and investors) to make their decisions. ${ }^{56}$ Thus, if it were proven that Uber manipulates its rating and review systems, then there could be room for an antitrust intervention, once Uber's dominant position was established.

In summary, though the advent of Uber has significantly changed the competitive dynamics in the transport sector, essentially the Uber case is not a matter for antitrust law, which usually welcomes new businesses and displacing technologies.

\footnotetext{
${ }^{54}$ See, e.g., Opinion of Advocate General Henrik Saugmandsgaard Øe of 21 September 2017, F. Hoffmann-La Roche Ltd e altri v AGCM, C-79/16, EU:C:2017:714., paragraphs 156-157, that recites that, "the concerted communication of misleading allegations (...) is, by its very nature, harmful to the proper functioning of normal competition, so much so that an examination of its effects on competition is not necessary. (...) where an examination of the content of the allegations in question reveals that they are misleading, the concerted communication of those allegations impairs the quality of the information available on the market and, consequently, adversely affects the decision-making process of those who create the demand for the two products concerned".

${ }^{55}$ In other words, as long as there are markets delivering information, there can be anticompetitive agreements, mergers and unilateral conduct limiting their output - that is, the amount of the information available to consumers - and the quality of business supply - that is, the accuracy and reliability of information.

${ }^{56}$ Mark Patterson, Antitrust Law in the New Economy (Harvard: Harvard University Press, 2017), 33-38. In particular, the Author analyses the cases of the firms that, like Google, Yelp, Amazon and Standard \& Poor's, provide people with the information that they use to make their consumption and investment decisions: "Although some consumers may continue to use multiple sources of information, many will not. Therefore, the products that Google or Amazon list with the lowest prices, or the products with the best reviews, are quite likely to be purchased more often than are other products. (...) As a result, shoppers may look only to that single source, making information providers like Google and Amazon critically important gatekeepers in their information markets" - at 33-38.
} 


\section{Conclusions}

It is a fact that Uber (but also Lyft and other ride-hailing companies) have notably affected the transportation market in many cities around the world. On the one hand, since the law regulates taxis' tariffs, the entry of the above digital rivals has pushed traditional taxis to improve the quality of their services. ${ }^{57}$ In addition, these new operators provide a reliable and affordable transportation option, serving neglected areas and providing employment. On the other hand, Uber and the like have raised many concerns, mainly with regard to safety, legality, and (unfair) competition with traditional operators.

In this article we have analysed the uncertainty over the legal qualification of Uber's services. Also, economists are working to evaluate the competitive effects of Uber empirically. The clash with incumbent operators and the innovation process put forward by emerging new technologies has been emblematically described by Judge Posner in a case appealed before the Seventh Circuit on the legitimacy of an ordinance of Chicago City applying specific rules to Transportation Network Providers (TNPs) and challenged by taxi and livery companies. ${ }^{58}$ Such ordinance, governing TNPs since 2014, is more permissive than the others governing taxi and livery services (e.g. it allows TNPs to set their own fares). Firstly the judgement clarifies that holding a licence to operate in a market does not imply the right to be free from competition in that market (that, in turn, undermines the justification for compensation for incumbent operators).$^{59}$ Then, according to the judgement, the different rules applied to TNPs are justified by the fact that their services are different and not interchangeable with taxi services. The major difference is that, in order to use Uber services, customers must sign up with the app, thereby creating a contractual relationship specifying terms (such as fares, driver qualifications, insurance), so that the passenger knows these elements in advance. Differently, taxis (and not

\footnotetext{
${ }^{57}$ For example, in the US, today's taxi drivers make sure that their cars are clean and provide features like operable credit card readers and air conditioning - see Scott Wallsten, "The Competitive Effects of the Sharing Economy: How is Uber Changing Taxis?”, (2015), accessed July 15, 2017. https://www.ftc.gov/system/files/documents/public_comments/2015/06/01912-96334.pdf.

${ }^{58}$ Illinois Transportation Trade Association v. City of Chicago (2016 WL 5859703).

${ }^{59}$ Other quotes from the judgment are worthy of mention: "Property" does not include a right to be free from competition. (...) When property consists of a license to operate in a market in a particular way, it does not carry with it a right to be free from competition in that market. (...)"; "[t]axi medallions authorize the owners to own and operate taxis, not to exclude competing transportation services".
} 
TNPs) are allowed to take on as passengers persons who hail them on the street, so that an ordinance aimed at protecting passengers by screening the drivers and by imposing a uniform system of rates is justified. ${ }^{60}$ Judge Posner adds: "when new technologies, or new business methods, appear, a common result is the decline or even disappearance of the old. Were the old deemed to have a constitutional right to preclude the entry of the new into the markets of the old, economic progress might grind to a halt".

Given these considerations, firstly it appears that the Uber saga is a matter of regulation. The main question on which regulators are struggling is whether to apply to Uber the same requirements applied to taxi drivers and other incumbent operators. Yet, we believe that this solution, that would imply the ban of Uber, is wrong.

Broadly speaking, there can be essentially two ways of regulating entrants introducing a new business model, i.e. extending the existing rules to the new emerging system, or using the latter to amend and innovate the former. ${ }^{61}$ We believe that the latter option is preferable.

To some extent, the Uber saga recalls the situation of many industries with high regulatory entry barriers in the years of liberalisation processes, where the opening of the markets to competition followed the stages and the manners established by legislation. The main difference with Uber (and other platforms, such as Airbnb) is that it engaged in a sort of "spontaneous liberalisation", as it started operating without necessarily obtaining regulatory approval. ${ }^{62}$ Thus, we support the idea that the peculiarities of Uber, as a matchmaker platform, ought not to be wasted and that it is not appropriate to apply to its services the same rules that have been designed for traditional operators.

Rather, two changes should be encouraged. On the one hand, legislators should enable the providers of traditional services to employ and exploit new technologies. When consumers find a legal offer satisfying their contemporary needs and wants, they will lose any incentive to turn to Uber. In other words, the best way to fight illegal business models is to develop legal business models that are equally good and efficient. After all, this is what the experience of copyright piracy teaches us. In addition, this is what is

\footnotetext{
${ }^{60}$ For an analysis of this judgment, see Andrea Boitani and Stefano Colombo, "Taxi, Ncc, Uber: Scontro Finale o Alba di Coesistenza?", Mercato Concorrenza Regole 1 (2017): 61, 67-78.

${ }^{61}$ Boitani and Colombo, "Taxi, Ncc, Uber", 63-64.

${ }^{62}$ Damien Geradin, "Uber and the Rule of Law: Should Spontaneous Liberalization be Applauded or Criticized?”, CPI (2015).
} 
already happening in those cities where "traditional" taxi companies have developed their own apps. On the other hand, legislators could decide to manage the advent of Uber and introduce specific rules about taxation and safety to safeguard the public interest.

In this perspective, the awaited judgement of the CJEU could constitute the opportunity to urge national governments to rethink the existing rules applied to incumbent operators with a view to improving their efficiency and quality for the benefit of consumers. ${ }^{63}$

\section{Bibliography}

Akman, Pinar. "A Competition Law Assessment of Platform Most-Favored-Customer Clauses", Journal of Competition Law and Economics 12 (2016): 781-833.

Anderson, Mark, and Max Huffman. "The Sharing Economy Meets the Sherman Act: Is Uber a Firm, a Cartel, or Something in Between?", Columbia Business Law Review (forthcoming).

Armstrong, Mark. "Competition in Two-Sided Markets", RAND Journal of Economics 37 (2006): 668-691.

Benkler, Yochai. "Sharing Nicely: On Shareable Goods and the Emergence of Sharing as a Modality of Economic Production”, The Yale Law Journal 114 (2004): 273-359.

Boitani, Andrea, and Stefano Colombo. "Taxi, Ncc, Uber: Scontro Finale o Alba di Coesistenza?”, Mercato Concorrenza Regole 1 (2017): 61-78.

Botsman, Rachel, and Roo Rogers. What's Mine Is Yours: The Rise of Collaborative Consumption. New York: Harper Collins, 2010.

Caillaud, Bernard, and Bruno Jullien. "Chicken and Egg: Competition among Intermediation Service Providers”, RAND Journal of Economics 34 (2003): 309-328.

Caillaud, Bernard, and Bruno Jullien. "Competing Cybermediaries", European Economic Review 45 (2001): 797-808.

Cannon, Bryant, and Hanna Chung. "A Framework for Designing Co-Regulation Models Well-Adapted to Technology-Facilitated Sharing Economies", Santa Clara High Technology Law Journal 31 (2015): 23-96.

Cohen, Molly, and Corey Zehngebot. "What's Old Becomes New: Regulating the Sharing Economy”, Boston Business Journal 58 (2014): 34-37.

Colangelo, Margherita. "Parity Clauses and Competition Law in Digital Marketplaces: The Case of Online Hotel Booking", Journal of European Competition Law \& Practice 8 (2017): 3-14.

${ }^{63}$ Ibid., 11. 
Cortez, Nathan. "Regulating Disruptive Innovation", Berkeley Technology Law Journal 29 (2014): 175-228.

Cramer, Judd, and Alan B. Krueger. "Disruptive Change in the Taxi Business: The Case of Uber", American Economic Review 106 (2016): 177-182.

Eckhardt, Giana M., and Fleura Bardhi. “The Sharing Economy Isn't About Sharing at All”, Harvard Business Review (Jan. 28, 2015), accessed July 15, 2017. https://hbr. org/2015/01/the-sharing-economy-isnt-about-sharing-at-all.

Edelman, Benjamin G., and Damien Geradin. "Efficiencies and Regulatory Shortcuts: How Should We Regulate Companies like Airbnb and Uber?", Stanford Technology Law Review 19 (2016): 293-328.

Eisenach, Jeffrey, and Thomas M. Lenard (eds). Competition, Innovation and the Microsoft Monopoly: Antitrust in the Digital Marketplace. Boston: Kluwer Academic Publisher, 1998.

Evans, David S. "The Antitrust Economics of Multi-Sided Platform Markets", Yale Journal on Regulation 20 (2003): 325-381.

Evans, David S., and Michael Noel. "Defining Antitrust Markets When Firms Operate Two-Sided Platforms", Columbia Business Law Review 3 (2005): 667-702.

Evans, David S., and Richard Schmalensee. "Failure to Launch: Critical Mass in Platform Businesses”, (2010), accessed July 15, 2017. https://ssrn.com/abstract=1353502.

Evans, David S., and Richard Schmalensee. Matchmakers. Harvard: Harvard Business Review Press, 2016.

Ezrachi, Ariel. "The Competitive Effects of Parity Clauses on Online Commerce", European Competition Journal 11 (2015): 488-519.

Geradin, Damien. "Online Intermediation Platforms and Free Trade Principles - Some Reflections on the Uber Preliminary Ruling Case”, April 2016, accessed July 15, 2017. https://ssrn.com/abstract=2759379.

Geradin, Damien. "Should Uber be allowed to Compete in Europe? And if so how?", Competition Policy International (2015).

Kaplan, Roberta A. "Regulation and the Sharing Economy”, New York Law Journal (2014). Katz, Vanessa. "Regulating the Sharing Economy", Berkeley Technology Law Journal 30 (2015): 1067-1126.

Koopman, Christopher, Matthew Mitchell, and Adam Thierer. "The Sharing Economy and Consumer Protection Regulation: The Case for Policy Change", Journal of Business, Entrepreneurship \& the Law 8 (2015): 529-545.

Kovacic, William E. "Antitrust in High-Tech Industries: Improving the Federal Antitrust Joint Venture", George Mason Law Review 19 (2012): 1097-1118.

Lerner, Adres V. "The Role of 'Big Data' in Online Platform Competition”, (2014), accessed July 28, 2017. http://ssrn.com/abstract $=2482780$. 
Loucks, Talia G. "Travelers Beware: Tort Liability in the Sharing Economy”, Washington Journal of Law, Technology \& Arts 10 (2015): 329-342.

Moore, Adrian T., and Ted Balaker. "Do Economists Reach a Conclusion on Taxi Deregulation?”, Economic Journal Watch 3 (2006): 109-132.

Morgan, Bronwen, and Declan Kuch. "Radical Transactionalism: Legal Consciousness, Diverse Economies, and the Sharing Economy", Journal of Law in Society 42 (2015): 556-587.

OECD. Taxi Services: Competition and Regulation, 2007.

Orsi, Janelle. Practicing Law in the Sharing Economy: Helping People Build Cooperatives, Social Enterprise, and Local Sustainable Economies. Chicago: American Bar Association, 2012.

Parker, Geoffrey, and Marshall W. Van Alstyne. "Two-Sided Network Effects: A Theory of Information Product Design", Management Science 51 (2005): 1494-1504.

Patterson, Mark. Antitrust Law in the New Economy. Harvard: Harvard University Press, 2017.

Rochet, Jean-Charles, and Jean Tirole. "Platform Competition in Two-Sided Markets", Journal of the European Economic Association 1 (2003): 990-1029.

Rogers, Brishen. "The Social Costs of Uber", University of Chicago Law Review Online 82 (2015): 85, accessed July 15, 2017. http://chicagounbound.uchicago.edu/ uclrev_online/vol82/iss1/6.

Romano, Valerio C. "Nuove Tecnologie per il Mitridatismo Regolamentare: Il Caso Uber Pop", Mercato Concorrenza Regole 1 (2015): 133-140.

Salop, Steven C., and David T. Scheffman. "Raising Rivals' Costs", The American Economic Review 73 (1983): 267-271.

Stucke, Maurice E., and Ariel Ezrachi. Virtual Competition. Harvard: Harvard University Press, 2016.

Terry, Nicolas P. "Regulatory Disruption and Arbitrage in Healthcare Data Proceedings", Yale Journal of Health Policy, Law, and Ethics 17 (2017): 143-207. 